\title{
GEOSÍMBOLOS RELIGIOSOS, SACRALIZACIÓN DEL ESPACIO Y LUGARES DE IDENTIDAD EN EL MICHOACÁN COLONIAL
} Religious geo-symbols, the sacredness of space, and places of identity in the colonial Michoacan

Sara Sánchez del Olmo

Investigadora asociada. Instituto Religiones, Culturas, Modernidad Universidad de Lausana (Suiza) e-mail: kleineulme@hotmail.com

RESUMEN: Analizamos aquí la transformación y redefinición del espacio michoacano a lo largo de la época colonial desde la óptica de lo religioso mostrando la importancia de los hospitales de indios en este proceso. La expansión de esta institución en Michoacán fue tal que el hospital se convirtió en un referente visual claramente identificable con significado e identidad propios, en un hito dentro de la nueva organización del territorio. Esa presencia, unida a la vivencia de lo sagrado dentro de sus muros, hicieron de él un auténtico geosímbolo religioso. Por otro lado, el hospital fue también un lugar de extroversión e irradiación del culto y constituyó el eje de un proceso de sacralización del espacio michoacano. Finalmente, la apropiación de la institución por parte de los naturales convirtió al hospital en un lugar de referencia y de pertenencia, en un elemento esencial en la reformulación de la identidad.

Palabras clave: Hospital de indios, geosímbolo, sacralización, identidad, Michoacán

ABSTRACT: The transformation and redefinition of the $m$ ichoacano space during the colonial era has been analyzed from a religious point of view, demonstrating through this process, the importance of Indian hospitals. The expansion of this institution in Michoacán has been so notable that the hospital has become a clear and verifiable visual referent, with its own meaning and identity, as well as a cornerstone in the new organization of the territory. Its existence, along with the sacred presence within its walls, has turned it into an authentic religious $g$ eosymbol. On the other hand, the hospital was also a place of extroverted and irradiated worship and has through time become the axis of the consecration process of the $m$ ichoacano space. Finally, the ownership of the institution by the natives turned it into a place of reference and of belonging as well as an essential element in the recasting of their identity.

Keywords: indian hospital, geosymbol, sacredness, identity, Michoacán 


\section{Introducción:}

Desde hace ya varios años investigadores de diferentes disciplinas se interesan por el análisis de la dimensión espacial de lo sagrado. Explorar las relaciones entre lugares, territorios, creencias y prácticas religiosas se ha convertido en uno de los ejes de los nuevos estudios culturales.

El trabajo que aquí abordamos analiza el hospital de indios michoacano entendido como un lugar privilegiado para la vivencia cotidiana de lo sacro en este territorio. Indagamos en la capacidad de esta institución para delinear y dar forma a un espacio y a un territorio sagrado y buscamos mostrar cómo, a lo largo de la época colonial, el hospital fue un elemento central en la reconstrucción de la identidad y en el proceso de reelaboración de las relaciones de los naturales con el espacio.

\section{La cristianización del territorio:}

La construcción del espacio es siempre expresión de un proceso complejo que revela valores, creencias e incluso ideales. Esto es bien evidente en América donde la fundación de ciudades y pueblos por parte del colonizador poseyó una fuerte significación simbólica y pragmática. Tras ese diseño del territorio se hallaba no sólo una voluntad de control sino, sobre todo, el deseo de imponer e inculcar nuevos principios en la sociedad dominada, el ansia por construir un nuevo mundo.

Una vez finalizada la conquista de las áreas centrales mesoamericanas, los españoles se enfrentaron al difícil reto de evangelizar y controlar política $\mathrm{y}$ económicamente grupos étnicos muy diversos que, en líneas generales, presentaban un patrón de poblamiento disperso y que, en numerosas ocasiones, habitaban además en sitios de difícil acceso ${ }^{1}$. La dispersión constituía un freno para la explotación de los recursos, la recaudación de tributos y la evangelización de la población por lo que la Corona diseño un programa destinado a reubicar a los naturales en sitios considerados

\footnotetext{
${ }^{1}$ Aunque a fines de la época prehispánica la mayor parte de los habitantes de Mesoamérica vivía en asentamientos dispersos con baja densidad de población, en el área central existieron también importantes núcleos urbanos con una alta densidad poblacional. Es el caso de ciudades como Tenochtitlan o Texcoco.
} 
mas propicios para la consecución de estos fines naciendo así los denominados pueblos de indios ${ }^{2}$.

Otra de las grandes preocupaciones de la Corona en ese momento eran las epidemias $^{3}$. Estas, además de provocar un auténtico desastre sanitario, estimularon también -al menos en un primer momento- la dispersión ya que numerosos grupos -tratando precisamente de escapar de la enfermedad- cambiaron de asentamiento y huyeron a los montes provocando incluso la despoblación de determinadas áreas ${ }^{4}$.

En Nueva España, tras la grave epidemia de 1545-48, la Corona convirtió en

${ }^{2}$ La preocupación por la reducción y congregación de la población indígena dispersa se manifestó de manera muy temprana en América y constituye uno de los ejes principales de la política indigenista española. Una de las primeras disposiciones es una instrucción dada en 1503 al gobernador de La Española, Nicolás de Ovando, para que los indios "se repartan en pueblos en que vivan juntamente", señalándose lugares destinados a la siembra y la crianza de ganado y, sobre todo, incidiendo en la necesidad de fomentar los espacios destinados a la evangelización. SOLANO, Francisco de. Normas y leyes de la ciudad hispanoamericana. 1492-1600, Madrid: CSIC, 1996, pp. 24-26. Tales recomendaciones, aparentemente benéficas, iban acompañadas de otras instrucciones secretas en las que la Corona indicaba a Ovando como principal finalidad la búsqueda, obtención y envío a España de todo el oro que se hallara en la isla, tarea que debían llevar a cabo exclusivamente los indios. La atracción de los indios a las poblaciones para ser cristianizados escondía así una intención marcadamente económica. La llegada a la isla de los Padres Jerónimos en 1516 marcaría definitivamente el rumbo de las congregaciones. Véase MOYA PONS, Frank. Después de Colón. Trabajo, sociedad y política en la economía del oro. Madrid: Alianza Editorial, 1987, pp. 37, 154 y 161. En Nueva España se hizo visible de manera evidente la importancia otorgada por los españoles a los espacios definidos y concentrados. El resultado fueron asentamientos bien delimitados en los que se centralizaban las funciones políticas y religiosas. La implantación de las nuevas estructuras fue gradual y hubo incluso un momento en el que la Corona pareció inclinarse hacia la convivencia de las repúblicas de indios y españoles. Así se desprende de una carta fechada en Medina del Campo el 20 de marzo de 1532 y enviada por la Reina a la segunda Audiencia novohispana como respuesta a una consulta de ésta sobre la conveniencia de juntar a los indios en poblaciones. La Reina afirmaba que para cristianizar y enseñarles la forma de vivir hispánica, nada mejor que mezclarlos de morada con los vecinos españoles. Para ello, proponía comenzar a experimentarlo con los indios que habían vivido en los monasterios. Véase ZAVALA, Silvio. El servicio personal de los indios en la Nueva España-I (1521-1550). México: El Colegio de México, 1984, p. 555. Finalmente, prevaleció el propósito de agrupar a los indígenas en espacios separados, sujetos a la Corona pero administrados por los propios naturales. El modelo se inspiraba en el precedente peninsular de los barrios judíos y musulmanes. Véase SOLANO, Francisco de. Ciudades hispanoamericanas y pueblos de indios. Madrid: CSIC, 1990, p. 24. Esta política fue acompañada de la implantación del régimen municipal. El ayuntamiento y el cabildo se convertían así en una vía más para la incorporación de los indígenas al nuevo sistema. Al tiempo, se introducían formas económicas desconocidas hasta entonces, con nuevos usos de la tierra y nuevas formas de propiedad, así como técnicas y productos de cultivo foráneos. Se trataba de implantar no sólo las instituciones sino también las formas de vida existentes en la península.

${ }^{3}$ Obviamente, las epidemias no eran desconocidas para las poblaciones indígenas. Sin embargo, antes de la llegada de los europeos, las enfermedades infecciosas habían tenido el carácter de brotes epidémicos. La conquista les otorgó una velocidad y una extensión desconocidas provocando un auténtico desastre sanitario. A los efectos de la enfermedad hay que unir los cambios en las dietas alimenticias y las costumbres higiénicas y, sobre todo, la explotación laboral, el excesivo peso de los tributos y los masivos desplazamientos de población. La combinación de todos esos factores provocó una disminución drástica de los naturales.

${ }^{4}$ Estos movimientos fueron especialmente activos tras la epidemia de 1580. 
imposición legal la concentración de los indios dictando nuevas directrices al respecto ${ }^{5}$.

Se buscaba establecer a la dispersa y menguada población en poblados más o menos grandes que formarían una red de aldeas dedicadas fundamentalmente a la agricultura y a la ganadería ${ }^{6}$. La llegada en 1550 del virrey Velasco dio un fuerte impulso al proceso de congregación. Muchos indios residentes en estancias apartadas fueron entonces obligados a abandonar sus agrupaciones ancestrales y centenares de ellas desaparecieron. En ese nuevo ordenamiento espacial los principales asentamientos indígenas, lugares de residencia del cacique o de la autoridad local, recibieron el nombre de cabeceras ${ }^{7}$, y los núcleos subordinados -ubicados a cierta distancia- fueron denominados estancias o sujetos ${ }^{8}$. Junto a ellos aparecieron también subdivisiones de carácter más local (ubicadas en la propia cabecera o fuera de ella) que recibieron el nombre de barrios o parcialidades ${ }^{9}$.

Aunque es innegable que la intervención hispánica supuso una radical transformación del paisaje americano, los pueblos de indios -como estructura urbana, política y social- fueron el resultado de la confluencia de elementos foráneos y autóctonos ${ }^{10}$.

${ }^{5}$ Paradójicamente, congregación de la población y desarrollo de las epidemias constituyeron dos fenómenos íntimamente ligados: por un lado, las epidemias provocaron el grave descenso poblacional y fueron una de las causas que condujeron a la Corona a congregar a los nativos. Por otro, con la concentración aumentaron las probabilidades de contagio y la propagación de las enfermedades.

${ }^{6}$ SOLANO, Francisco de. Urbanización y municipalización de la población indígena en Estudios sobre la ciudad iberoamericana (Francisco. Solano, coord.). Madrid: CSIC, 1983, p. 244.

${ }^{7}$ Hubo también pueblos que contaron con cabeceras múltiples o asociadas. Además, con los procesos de congregación, determinados sujetos adquirieron gran importancia llegando a competir en el siglo XVII con sus respectivas cabeceras. Esto condujo en ocasiones a la separación definitiva.

${ }^{8}$ GERHARD, Peter. Geografía histórica de la Nueva España, 1519-1821. México: UNAM, 1986, p. 27. En lineas generales, el término se aplicó a los poblados indígenas dispersos dependientes de la cabecera en lo político, económico y religioso. En ocasiones, la distancia que separaba la cabecera de algunos de sus sujetos era notable.

9 Desde el punto de vista hispánico los barrios eran concentraciones espaciales de individuos, meras subdivisiones locales de una entidad mayor. Sin embargo, desde el punto de vista indígena, tras estas agrupaciones se "ocultaban" relaciones de parentesco, alianzas y vínculos con los linajes. Según García Castro, los barrios contaban con un líder con un título específico de menor rango que el tlatoani y estaban compuestos a su interior por "nobles" y "plebeyos" relacionados social, económica y políticamente por fuertes lazos de lealtad y dependencia. GARCÍA CASTRO, René: Indios, territorio y poder en la provincia Matlatzinca. La negociación del espacio político de los pueblos otomianos, siglos XV-XVII. México: CIESAS-I.N.A.H.-El Colegio Mexiquense, 1999, pp. 36-39. Por otro lado, no todos los barrios fueron iguales en jerarquía. Por razones diferentes (presencia de un linaje importante, acumulación paulatina de derechos y privilegios, asiento de un mercado...) algunos detentaron una primacía sobre los demás. Obviamente, en las villas y ciudades de españoles también hubo presencia indígena por lo que alrededor de los centros aparecieron también barrios de indios.

${ }^{10}$ Muchos de los nuevos asentamientos fueron construidos sobre espacios previamente habitados. De hecho, la toponimia revela la existencia de numerosos enclaves anteriores a la llegada de los españoles. 
Sin duda, una de las consecuencias mas significativas del nuevo reordenamiento espacial fue la centralización de las funciones políticas, económicas, administrativas y religiosas lo que contribuyó a crear núcleos privilegiados y a establecer relaciones altamente jerárquicas entre las cabeceras y los centros subordinados. A partir de ese momento la estructura flexible que había caracterizado a la época prehispánica quedó fracturada.

La reorganización del territorio implicó el diseño de nuevos modelos urbanos, modelos que constituyen el eje y el reflejo de un sistema de producción y organización del poder. Por esa razón, su forma física y su implementación pueden ser analizadas como la expresión de un proyecto ideológico ${ }^{11}$.

Entre las tipologías desplegadas destaca sin duda el denominado "trazado clásico", que simulaba un tablero de ajedrez y en el que las calles eran delineadas a compás y cordel $^{12}$. En él sobresalía la plaza mayor, formada por una cuadra vacía, ubicada generalmente en el centro del área urbana y rodeada por las sedes de la autoridad ${ }^{13}$. El damero era la expresión física de un determinado ordenamiento cultural: era como bien ha señalado Durston (1994)- el espacio de la vigilancia en el que todas las costumbres "apolíticas" del indígena podían ser detectadas y erradicadas ${ }^{14}$. Herramienta de socialización -y de aculturación- el damero imponía y hacía visible el ideal de orden que debía regir la republica así como la jerarquía social existente dentro de la misma ${ }^{15}$.

Por otro lado, las jurisdicciones coloniales respetaron -en lo esencial- la organización y linderos de los antiguos señoríos prehispánicos.

${ }^{11}$ El proceso se encuentra claramente especificado en las Ordenanzas promulgadas por Felipe II en 1573. Estas constituyen el hecho culminante de la legislación hispánica en materia de urbanismo y de la práctica desplegada en América durante casi una centuria. Constan de 148 capítulos de los cuales más de veinte se refieren al trazado.

12 Aunque se trata de una premisa en la que confluyen varias herencias culturales, no debe olvidarse que desde el punto de vista simbólico el cuadrado es, en la cultura occidental, expresión geométrica de los cuatro elementos, de las cuatro estaciones y, sobre todo, de los cuatro puntos cardinales. SEBASTIÁN LÓPEZ, Santiago. Espacio y símbolo. Córdoba: Universidad de Córdoba, 1977. Simboliza el universo creado, limitado y estable, y a través de él se expresan aquellas realidades que se tienen por definitivas. REVILLA, Federico. Diccionario de iconografía y simbología. Madrid: Editorial Cátedra, 1999, p. 128. El cuadrado en el urbanismo es, por tanto, una forma simbólica de otorgar carácter definitivo a un espacio. Y no hay que olvidar que el cuadrado es también el símbolo que define a la Jerusalén terrestre, paradigma de la nueva humanidad. No es extraño pues que en el Nuevo Mundo los espacios nacidos a una nueva vida fueran concebidos, como la nueva Jerusalén, cuadrados (Apocalipsis, 21, 16: "La ciudad es cuadrada: su ancho es igual a su largo"). Serán precisamente las Ordenanzas de 1573 las que consoliden la ciudad cuadriculada.

${ }^{13}$ En Nueva España, la mayor parte de los pueblos de indios fueron concebidos siguiendo precisamente este modelo.

${ }^{14}$ DURSTON, Alan. Un régimen urbanistico en la América hispana : el trazado en damero durante los siglos XVI y XVII. Historia. Santiago (Chile), vol. 21, pp. 59-115, 1994.

15 En el reparto de solares se hacía presente la estructura jerárquica de la sociedad y el ordenamiento interno de la misma anterior a la llegada de los españoles: caciques y principales eran los primeros en recibirlos y tras ellos, los naturales. El tamaño de los solares constituía un marcador socio-económico al igual que la ubicación de los mismos. En el nuevo orden espacial la plaza aparecía como el núcleo vertebrador y, al tiempo, como el símbolo visual del nuevo poder, el político -con la presencia del cabildo- y el religioso - con la iglesia-. Las élites recibieron así los terrenos próximos a la plaza. 
El proceso de fundación de los pueblos de indios constituyó un ejercicio de puesta en escena de una ideología. Además de una innegable finalidad socio-económica, el proceso de congregación poseía un fuerte componente simbólico: se trataba de reconvertir áreas "paganas" en espacios cristianos siguiendo los presupuestos del Apocalipsis, "Ecce nova facio omnia"16. La apropiación-reorganización del territorio fue acompañada así de una operación simbólica en la que se hicieron visibles diferentes rituales ${ }^{17}$. Como los propios habitantes, el espacio debía también nacer a una "nueva vida". El primer paso era el "bautismo", ritual que habría de servir para "liberarlo" de su "pecado original" y sacarlo, al igual que a los indios, de su pasado pagano para convertirlo en un espacio cristiano. Este protocolo de posesión consistía fundamentalmente en otorgar un nombre al pueblo. Como ha señalado Claval (1999), dar nombre al lugar significaba impregnarlo de cultura y de poder ${ }^{18}$. En numerosas ocasiones, esta operación se realizó añadiendo un apelativo cristiano al topónimo indígena ${ }^{19}$. Al "bautismo" le seguían diversas ceremonias iniciáticas como la instalación de cruces $^{20}$; estas señalaban el centro -físico y simbólico- del pueblo y constituían el referente material a partir del cual había de definirse la traza espacial. La instalación de la cruz delimitaba un perímetro de lo sagrado, un ámbito que incluía al pueblo de indios en su totalidad ${ }^{21}$. Finalmente, éste era "santificado" mediante la celebración del rito de la eucaristía. Sólo entonces era posible proceder a su ordenamiento y puesta en policía, incorporarlo al modo de vida "civilizado"22.

Una vez realizadas estas operaciones simbólicas llegaba el momento de erigir los elementos definitorios y característicos del pueblo de indios: la plaza, el cabildo y la iglesia. Esta ultima constituía, sin ninguna duda, el lugar más visible y mas compacto, el signo más evidente de la "conversión” del espacio.

\section{Nuevas cartografías:}

En Michoacán las primeras cuatro décadas de la historia colonial (1522-1564) resultan fundamentales para comprender el profundo proceso de transformación sufrido

\footnotetext{
${ }^{16}$ Apocalipsis, 21: 5: "He aquí que todo lo hago nuevo".

${ }^{17}$ A este respecto véase SÁNCHEZ DEL OLMO, Sara. El texto como pretexto. Un relato histórico sobre la fundación de un pueblo de indios en el Michoacán colonial. En : SÁNCHEZ BAENA, J.J., PROVENCIO GARRIGÓS, L., coord.). El Mediterráneo y América, vol. 2. Murcia: Universidad de Murcia, 2006, pp. 765-779.

${ }^{18}$ CLAVAL, P. La geografía cultural. Buenos Aires : Editorial Universitaria (EUDEBA), 1999, p. 173

${ }^{19}$ Es preciso recordar que la toponimia, en cuanto forma simbólica, posee en numerosas ocasiones una fuerte connotación político-territorial e identitaria.

${ }^{20}$ En la historia del cristianismo, la cruz no es sólo el recuerdo del sacrificio de Cristo; es además, síntesis

y medida ya que a través de ella se unen cielo y tierra, tiempo y espacio. Sería el cordón umbilical y el centro del mundo, la comunicación permanente tierra-cielo.
}

\footnotetext{
${ }^{21}$ Diversos elementos de arquitectura religiosa diseminados a lo largo y ancho de los pueblos de indios como altares callejeros, vía crucis y calvarios- contribuían a reforzar ese carácter sagrado del espacio.

${ }^{22}$ Vivir en policía significaba vida en república, esencialmente, vida urbana.
} 
por la sociedad indígena. Y en ese cambio jugó un papel determinante el nuevo diseño del espacio, metáfora de la construcción de una nueva sociedad.

A la llegada de los españoles Michoacán se caracterizaba por un patrón de poblamiento disperso ${ }^{23}$ en el que tres centros, Tzintzuntzan, Ihuatzio y Pátzcuaro, sobresalían ${ }^{24}$. Dichos asentamientos contaban con funciones administrativas, comerciales y religiosas que se complementaban entre sí. Durante el siglo XIV Tzintzuntzan había tomado la primacía como centro administrativo, mientras que Ihuatzio constituía "la imagen simbólica del poder"25. Allí era elegido el cazonci"26 aunque la autoridad política era ejercida desde Tzintzuntzan. En ambos centros vivía la élite gobernante. Pátzcuaro parece haber ocupado el último lugar en esta trilogía, situación que se transformaría radicalmente a partir del siglo XVI.

El espacio dominado por el cazonci poseía, al igual que en otras culturas mesoamericanas, un doble carácter: físico y simbólico. El mundo habitado por los seres humanos constituía el paraquahpen; no se trataba de una simple entidad territorial sino de una realidad viva que, a semejanza de un cuerpo humano acostado boca abajo, tenía sus pies en el oriente y su cabeza en el poniente. Consecuentemente, los pueblos que se encontraban al sur, en la denominada Tierra Caliente, se ubicaban "a la mano

\footnotetext{
${ }^{23}$ Como hemos señalado, muchos de los pueblos de indios se levantarían sobre espacios previamente habitados y organizados políticamente. En la Relación de Michoacán -una de las fuentes sustanciales para conocer el proceso de conquista del territorio michoacano- aparecen mencionados numerosos pueblos que "sobreviven" en época colonial. Tal es el caso, por ejemplo, de Zacapu, Sivinan, Naranjan, Cuiseo, Uruapan o Tancítaro. Véase Relación de Michoacán. Versión paleográfica e introducción de Armando Mauricio Escobar Olmedo. Madrid: Testimonio Compañía Editorial, 2001, segunda parte, cap. XXXI, pp. 499-502. Existen varias ediciones de la Relación; la que aquí citamos es una edición preparada por Escobar que revisa la paleografía de las anteriores.

${ }^{24}$ A pesar de a la existencia de un poder central, en el Michoacán prehispánico nunca se desarrolló un centro urbano de grandes proporciones.

${ }^{25}$ BELTRÁN, Ulises. Estado y sociedad tarascos en la época prehispánica. En BOEHM DE LAMEIRAS, Brigitte (coord.). El Michoacán Antiguo, Estado y Sociedad Tarascos en la Época Prehispánica México: COLMICH y Gobierno del Estado de Michoacán, 1994, p. 118.

${ }^{26}$ Cazonci es el término comúnmente empleado para referirse a la máxima autoridad política de Michoacán. Los sacerdotes y nobles tarascos se dirigían a su rey llamándolo "hombre valiente", qhuangua pero parece que le designaban con el nombre de irecha. Sin embargo, el vocablo más frecuente para referirse a él es cazonci, ya que ésta es la forma empleada en los escritos del siglo XVI. Se trata de una palabra nahuatl que significa "el que siempre está calzado con cactles (sandalias) y no se descalza". El término está vinculado a la tradición indígena de presentarse descalzos ante el rey. El señor de Michoacán, al no ser vasallo de nadie, jamás se descalzaba. Autores como Mauricio Swadesh apuntan al origen tarasco del término, que significaría "el de la cabeza rapada". Véase LÓPEZ SARRELANGUE, Delfina E. La nobleza indígena de Pátzcuaro en la época virreinal. México: UNAM-Instituto de Investigaciones Históricas, 1965, pp. 30-32. El cazonci o irecha era el jefe supremo de la iréchecua, una unidad territorial y política conformada a lo largo de años y compuesta por diversas irétecha o pueblos.
} 
izquierda", mientras que los serranos se hallaban "a la mano derecha" 27 . Por otro lado, los puntos relevantes y los accidentes geográficos poseían nombre y también carácter sexual $^{28}$. Las congregaciones provocaron no sólo una profunda transformación del espacio sino también de la relación físico-simbólica establecida con él por las diferentes poblaciones indígenas ${ }^{29}$.

A pesar de todo, determinados elementos del mundo prehispánico pervivieron y se hicieron presentes en el nuevo ordenamiento. Así por ejemplo, las unidades de organización basadas en el parentesco (que en la zona purhépecha correspondían a las apázecua o huapánekua) fueron territorializadas y cobraron cuerpo a través de los barrios del pueblo de indios.

Las primeras reducciones fueron realizadas poco tiempo después de la conquista del territorio: autoridades civiles y religiosas se esforzaron por apuntalar las bases de este nuevo modelo centrado en la fundación de pueblos de indios. A lo largo del siglo XVI el territorio fue testigo de diversos procesos de congregación ${ }^{30}$. Uno de los más activos se produjo a partir de 1595 cuando una nueva demarcación procedió a reelaborar el orden espacial preexistente. Este reacomodo, que afectó sobre todo a los pueblos sujetos $^{31}$, contó con fuertes resistencias por parte de los indígenas ${ }^{32}$. Se buscaba,

\footnotetext{
${ }^{27}$ MONZÓN, Cristina.

${ }^{28}$ GARCÍA MORA, Carlos. El espacio y el tiempo purépechas. Intersección cardinal en un poblado de la Sierra de Michoacán (ed. Electrónica). México: Tsimarhu Estudio de Etnólogos, 2014, pp. 9-10.

${ }^{29}$ Pese a todo, los naturales lograron mantener vivas formas de construcción y representación territorial características de la época prehispánica. Un buen ejemplo de ello es el valor simbólico otorgado a los
} cerros.

\footnotetext{
${ }^{30}$ En líneas generales puede afirmarse que en Michoacán -al igual que en otras áreas mesoamericanas- la formación de los pueblos de indios supuso en numerosas ocasiones un trauma para las poblaciones indígenas ya que no se tuvieron en cuenta las diferencias culturales de modo que etnias diversas quedaron englobadas en un único grupo. Incluso, en algunos casos, etnias rivales entre sí fueron agrupadas en un mismo núcleo lo que provocaría no pocas tensiones internas. Por otro lado, como bien ha señalado Castro Gutiérrez, en algunas ocasiones las congregaciones fueron aprovechadas por determinados grupos indígenas para aumentar su influencia y perjudicar a adversarios locales. Véase CASTRO GUTIÉRREZ, Felipe. Los tarascos. México: UNAM, 2004, p. 77.

${ }^{31}$ Un claro ejemplo de esta política son las instrucciones dadas por el virrey don Gaspar de Zúñiga y Acevedo, conde de Monterrey, a Fernando de Villegas, alcalde mayor de la Provincia de Michoacán en 1601. Véase DE LA TORRE VILLAR, Ernesto. Las congregaciones de los pueblos de indios. Fase terminal: aprobaciones y rectificaciones. México: UNAM, 1995, pp. 315-327.

32 Archivo General de la Nación - México (en adelante A.G.N.). Congregaciones, Vol. I, Expediente 4, Hoja 3v-4; Expediente 15, Hoja 9v-10; Expediente 23, Hoja 13-16v; Expediente 28, Hoja 18v-19;
} 
fundamentalmente, consolidar las estructuras ya existentes favoreciendo el mayor control económico y social de la población. Las autoridades instaron entonces al abandono de determinados asentamientos y para lograrlo no dudaron en recurrir a métodos coercitivos ${ }^{33}$. A pesar de que el programa debía afectar sólo al espacio residencial manteniéndose las tierras, los bosques y los recursos naturales según la posesión anterior, en la práctica surgieron numerosos conflictos jurisdiccionales y agrarios $^{34}$. Dado que la reorganización implicaba la creación o delimitación de nuevas jurisdicciones civiles y religiosas, surgieron conflictos con algunos pueblos transformados en sujetos ya que los rangos iban acompañados de privilegios y obligaciones. Estaban en juego, por ejemplo, la jerarquía política y la prestación de servicios personales ${ }^{35}$. Por otro lado, la reordenación del territorio provocó una fuerte lucha por la tierra y reavivó conflictos que, en algunos casos, se remontaban a la época prehispánica $^{36}$.

Finalmente, las congregaciones provocaron el inició de un proceso sin retorno: la integración de los naturales en la sociedad colonial y la preeminencia, en términos generales, de una identidad vinculada a un pueblo. En ese nuevo marco de referencia y en ese nuevo espacio de pertenencia, determinadas instituciones socio-religiosas adquirieron un valor físico y simbólico primordial.

\section{Los hospitales de indios: nuevos geosímbolos religiosos del espacio michoacano}

En Michoacán, el proceso de congregación de la población encontró un férreo defensor en la figura del primer obispo de la diócesis, Vasco de Quiroga. El abulense compartía con la Corona la idea de que la dispersión espacial era perniciosa para la población indígena y consideraba que la reordenación del territorio era el medio más efectivo para lograr la hispanización ${ }^{37}$. La mejor muestra de la aceptación de estas

Expediente 62, Hoja 39v-42; Expediente 98, Hoja 63v-64; Expediente 106, Hoja 66; Expediente 117, Hoja 69-69v.

33 A.G.N. (México), Congregaciones, Vol. I, Expediente 114, Hojas 68-68 v.

${ }^{34}$ PAREDES MARTÍNEZ, Carlos. Gobierno y pueblos de indios en Michoacán en el siglo XVI en PAREDES, Carlos (dir.). Arquitectura y espacio social en poblaciones purépechas de la época colonial. Morelia: Universidad Michoacana de San Nicolás de Hidalgo, 1998, p. 27.

${ }^{35}$ Un claro ejemplo de este enfrentamiento son Pomacuarán y Aranza (Arantzán). Véase CÉSAR VILLA, $\mathrm{M}^{\mathrm{a}}$ Guadalupe. Las congregaciones de tres pueblos de indios en tres partidos serranos y sus consecuencias en el siglo XVII. En: PAREDES, Carlos. Arquitectura y espacio social..., p. 57.

${ }^{36}$ CÉSAR VILLA, M ${ }^{a}$ Guadalupe. Las congregaciones de tres pueblos de indios en tres partidos serranos y sus consecuencias en el siglo XVII. En: PAREDES, Carlos. Arquitectura y espacio social..., pp. 58-61.

${ }^{37}$ A pesar de ser un férreo defensor de este proceso Quiroga no siempre estuvo de acuerdo en la forma en que éste se realizaba. Así lo muestra al menos una carta escrita por él en 1561 en la que pide una 
premisas fue el traslado de la sede episcopal desde Tzintzuntzan a Pátzcuaro y la posterior concentración de población llevada a cabo en esta última ${ }^{38}$. Desde 1538 hasta

1542 numerosos asentamientos completos de las áreas circundantes a la ciudad fueron trasladados a ésta al tiempo que se establecían grupos más pequeños en las riberas del lago de tal forma que, según algunos autores, el antiguo señorío tarasco fue el primer espacio de la Nueva España en contar con asentamientos de diseño europeo ${ }^{39}$.

Quiroga se hizo cargo de una diócesis que abarcaba casi 140.000 kilómetros cuadrados. Para organizar tan vasto territorio, el obispo -en función de su estrategia de evangelización- buscó estructurarlo en centros urbanos ${ }^{40}$ en los que los hospitales de indios eran un elemento fundamental ${ }^{41}$. Estos constituyeron el eje axial de su labor episcopal $^{42}$ y su desarrollo se halla estrechamente ligado al propio diseño del espacio ${ }^{43}$.

provisión real para que allí donde haya “...juntos en policía de cincuenta para arriba con su iglesia, gobernador, principales y regidores que rijan, que no se deshaga para juntarse con otro pues diez hacen pueblo según derecho...". Parece que en numerosas ocasiones algunos frailes destruían las iglesias y las casas de los naturales para obligarles a reasentarse en la cabecera donde se hallaba el monasterio, juntando a los indios “...a su conveniencia...”. Archivo General de Indias (En adelante A.G.I.), México, 374 , f. 9r. y v.

Los sucesores del obispo parecen haber estado de acuerdo con estos procesos de congregación. Asi se desprende de una carta del obispo Antonio Ruiz de Morales y Molina escrita en 1569, poco después de la muerte de Quiroga. El prelado insistía que la dispersión y lejanía de los sujetos hacía difícil el adoctrinamiento de los indios por lo que instaba a su congregación, aunque recomendaba también que se permitiese a los naturales escoger el lugar donde asentarse y congregarse. A.G.I., México, 374, f. 51 r. y $\mathrm{V}$.

38 A partir de 1539 los pueblos sujetos a Tzintzuntzan, antigua capital del reino tarasco, pasaron a pertenecer a la nueva cabecera. Pero al mismo tiempo, en este proceso de reorganización territorial Pátzcuaro fue privado de algunos de sus mejores pueblos, los situados junto a la laguna, que le serían restituidos en 1553. El traslado de la capitalidad de la diócesis a este nuevo emplazamiento causaría no pocos problemas a Quiroga, especialmente frente a Tzintzuntzan y sus habitantes, que reclamaban sus derechos. La mudanza implicaba también el desplazamiento de las autoridades civiles por lo que la designación de este nuevo espacio como centro de la evangelización provocó un duro enfrentamiento entre los poderes eclesiástico y civil. Al mismo tiempo, el traslado provocó una profunda brecha en el seno de las élites indígenas michoacanas. De hecho, los herederos del cazonci, los nobles, el gobernador indígena y el cabildo se opusieron con firmeza a este traslado.

${ }^{39}$ GERHARD, Peter. Congregaciones de indios en la Nueva España antes de 1570. En: Los pueblos de indios y las comunidades (Bernardo García, introducción y selección). México: El Colegio de México, 1991, pp. 49-50.

${ }^{40}$ VIÑUALES, Graciela M.; GUTIÉRREZ, Ramón y otros. Iberoamérica siglos XVI-XVIII. Tradiciones, utopías y novedad cristiana. Madrid: Ediciones Encuentro, 1992, pp. 48-49.

${ }^{41}$ Desde la perspectiva de las autoridades civiles y religiosas, la institución se perfilaba como un activo instrumento para la incorporación de los naturales al orden colonial: instalados en los centros de población "atraerían" a los indígenas, quienes buscarían en ellos alivio a sus necesidades sanitarias y materiales. Al mismo tiempo, constituían eficaces centros de evangelización y conversión. Aunque los hospitales de indios formaron parte del diseño territorial del Nuevo Mundo, el éxito de la institución en Michoacán fue extraordinario.

${ }^{42}$ El jesuita Francisco Ramírez refiere y resume de alguna manera los tres pilares fundamentales de la labor obispal del abulense: "...la primera, lo tocante a la hospitalidad y ayuda de pobres enfermos; segunda, la educación de la juventud; tercera, crear ministros suficientes para la administración de los sacramentos y propagación del santo evangelio...". Para lo primero, según el propio cronista, “...dio orden 
La institución, concebida como un elemento central del nuevo orden político y religioso y de la propia ordenación consciente del territorio, caminó así de forma paralela a los procesos de congregación de la población, siendo parte esencial de su desarrollo y evolución ${ }^{44}$. De esta manera, en Michoacán, el hospital se convirtió en “...el germen de un fenómeno urbanístico en los pueblos de indios..." 45.

A pesar de que Quiroga posee el innegable mérito de ser el principal promotor de la institución en esta diócesis, la expansión y el desarrollo de los hospitales de indios en Michoacán no puede entenderse si no se profundiza en el papel jugado por los indígenas. Las razones de la rápida y positiva aceptación de la institución por parte de los naturales son diversas pero, en líneas generales, su "éxito" ha de vincularse a las posibilidades que el hospital ofrecía para la pervivencia de numerosos elementos culturales de época prehispánica pero también para la apropiación de nuevas prácticas vinculadas a la cultura hegemónica ${ }^{46}$. Su vigor y su fortaleza derivan, en gran medida, de la multiplicidad de funciones contenidas en su interior $\mathrm{y}$, sobre todo, de su efectividad y su capacidad para articular la vida del pueblo de indios. A ello hay que añadir la autonomía de la institución que funcionaba sin apenas intervención de las autoridades civiles y religiosas hispánicas.

Desde fechas tempranas, los hospitales se convirtieron en un lugar privilegiado para la vivencia de lo sagrado. En el mundo indígena, esta dimensión penetraba el mundo material y la vida cotidiana. Tras la conquista, los naturales se vieron a obligados a buscar nuevos lugares en los que depositar la sacralidad con el fin

cómo en todos los pueblos de indios hubiese hospitales..." promoviendo así la existencia de toda una red a lo largo de la diócesis michoacana. RAMÍREZ, Francisco. El Antiguo Colegio de Pátzcuaro (Germán Viveros, ed.). Zamora (Michoacán): COLMICH, 1987, cap. II, pp. 71-72.

Obviamente, la fundación de los numerosos nosocomios de indios existentes en Michoacán no se debe exclusivamente al abulense: agustinos y franciscanos - entre los que destaca el nombre de fray Juan de San Miguel- fueron activos promotores de esta institución. Sin embargo, Quiroga jugó un papel determinante en la extensión de la misma ya que, para él, la fundación de hospitales constituyó parte esencial del diseño y la organización misma de la diócesis. El éxito de su proyecto fue tal que el hospital de indios se convirtió en el elemento más significativo de la misma.

${ }^{43}$ Dado que su fundación estaba contemplada en la propia legislación colonial no necesitaban permisos de erección por lo que es casi imposible establecer una serie cronológica de las fundaciones.

${ }^{44}$ La historia de ambos sería paralela: el auge y declive de los pueblos de indios michoacanos tendría su inmediato reflejo en la institución.

${ }^{45}$ PAREDES MARTÍNEZ, Carlos. Gobierno y pueblos de indios en Michoacán, p. 41.

Aunque los hospitales de indios formaron parte del diseño territorial del Nuevo Mundo, el éxito de la institución en Michoacán fue extraordinario.

${ }^{46}$ SÁNCHEZ DEL OLMO, Sara. Les hôpitaux d'indiens au Michoacan : survivance et appropriation culturelle à la Nouvelle Espagne (1536-1639). En: GRUNBERG B. (ed.). Le contrôle de la vie religieuse en Amérique. Paris : L'Harmattan, 2008, pp. 47-64. 
de garantizar su pervivencia. La nueva religión posibilitó -a través de nuevos intermediarios, nuevos signos externos y nuevos espacios como los hospitales- una vivencia activa de lo sacro. Si bien es cierto que los comienzos no fueron fáciles ${ }^{47}$, en el momento de constituirse la estructura diocesana, los naturales michoacanos estaban plenamente inmersos en las prácticas devocionales cristianas $^{48}$. Apenas dos generaciones después de la conquista la nueva ritualidad estaba muy arraigada. Convencidos o coaccionados, en la segunda mitad del siglo XVI el catolicismo constituía una de las señas de identidad de los pueblos de indios de este territorio ${ }^{49}$.

Más que ningún otro lugar, el hospital permitía a los naturales una inmersión completa en lo sagrado: cada semana, un pequeño grupo de hombres y mujeres se separaba del mundo para dedicarse no sólo al cuidado de los enfermos sino a la práctica ritual de la oración, los sacramentos y la vida comunitaria ${ }^{50}$. El carácter sacro de la institución fue interiorizado hasta el punto de que la entrada en dicho lugar conllevaba no sólo el "aislamiento físico" sino la abstinencia sexual" ${ }^{51}$. Como bien ha señalado Carrillo Cázares (1993), el hospital ofrecía el mayor espacio abierto al servicio de los laicos en favor de la comunidad ${ }^{52}$. El veto impuesto a los naturales para el acceso a los puestos de gobierno en la Iglesia halló aquí una puerta abierta al permitirles el ejercicio de cargos no sólo temporales sino, sobre todo, espirituales.

Por otro lado, los hospitales se convirtieron en una privilegiada puerta de entrada al ámbito sobrenatural ya que en ellos se garantizaba el cumplimiento de los ritos necesarios para obtener la salvación desde la perspectiva cristiana. Allí, los indígenas

\footnotetext{
${ }^{47}$ CASTRO, Felipe. Los tarascos, pp. 243-244.

${ }^{48}$ Los aspectos externos constituían una parte esencial de la vida religiosa pero resulta difícil conocer hasta qué punto los dogmas y principios teológicos fueron asumidos e interiorizados por los naturales. La fusión -y confusión- de formas y creencias fue, probablemente, uno de los elementos más característicos de este proceso

${ }^{49}$ Hasta finales de la época colonial estuvo bien vigente la idea de que los indios eran buenos católicos pero malos cristianos. TAYLOR, William. Ministros de lo sagrado. Zamora (México): El Colegio de Michoacán, 1999, vol. I, p. 74.

${ }^{50}$ BASALENQUE, Fray Diego de. Historia de la provincia de San Nicolás de Tolentino de Michoacán [1673]. Morelia (México): Balsal Editores, 1989. Libro I, cap. IIII, fol. 21 v.

${ }^{51}$ Así lo recoge el canónigo Ysassi quien en la descripción del Obispado realizada en 1649 señalaba que los indígenas que entraban a servir al hospital "...no salen de día ni de noche fuera; ni en aquella semana que les caben cohabitan las mujeres con sus maridos, ni los maridos con las mujeres, porque les parece que es desacato a la Virgen Santísima a cuyo servicio se dedican aquel tiempo. Y esto es general en todo el Obispado...”. YSASSI, Francisco Arnaldo de. Demarcación y descripción del obispado de Michoacán y fundación de su catedral. Biblioteca Americana, University of Miami, Station Coral Gables, Florida, vol.1, n 1, pp. 61-209, 1982.

${ }^{52}$ CARRILLO CÁZARES, Alberto. Michoacán en el otoño del siglo. Zamora (México): El Colegio de Michoacán, 1993, p. 149.
} 
recibían "la última recomendación", es decir, ese conjunto de oraciones en las que se solicitaba a Dios el perdón del alma y se invocaba a los santos para que la amparasen y la protegiesen en los peligros que pudieran acecharla ${ }^{53}$. Al mismo tiempo, los hospitales procuraban a los naturales fallecidos entre sus muros un entierro digno y en sagrado. Las semaneras, mujeres indígenas que entraban por turnos a servir en el hospital, fueron quienes habitualmente prepararon los cadáveres asegurando a las almas el tránsito adecuado. De esta manera, el hospital se convirtió en un espacio privilegiado para la vivencia colectiva y convenientemente ritualizada de la muerte y el paso al Más allá ${ }^{54}$.

El carácter sacro de la institución quedaba reforzado por la presencia de pequeñas capillas anexas ${ }^{55}$. Estas jugaron un papel esencial en el desarrollo de la religiosidad ya que fueron los espacios que, habitualmente, albergaron la oración, las celebraciones litúrgicas y la práctica sacramental ${ }^{56}$. Dedicadas mayoritariamente a La Concepción, al igual que la institución matriz, su importancia física y simbólica fue tal que en ocasiones "compitieron" con las iglesias parroquiales ${ }^{57}$. Y es que mientras estas últimas eran imprescindibles dentro de la traza urbana, las capillas hospitalarias respondían tan sólo a la voluntad de los indígenas por erigirlas ${ }^{58}$. Eran por tanto propiedad del común, sitios sagrados controlados exclusivamente por los naturales ${ }^{59}$.

\footnotetext{
${ }^{53}$ Ysassi señala que en aquellos hospitales con mayores bienes se decían misas a todos los difuntos del pueblo. Ysassi, Francisco Arnaldo. Demarcación y descripción del obispado de Michoacán..., p. 143.

${ }^{54}$ Resultan muy interesantes los comentarios del cronista La Rea quien afirma que los indígenas, una vez que recibían los santos óleos, "se dejaban morir". Los propios semaneros, una vez oleado, les cubrían el rostro y les daban por muertos. REA, Alonso de la. Crónica de la Orden de N.S.P. San Francisco, Provincia de San Pedro y San Pablo de Michoacán en la Nueva España [1643]. Edición y estudio introductorio de Patricia ESCANDÓN. Zamora (México): El Colegio de Michoacán, 1996. Libro segundo, cap. VI, p. 162.

55 El Tercer Concilio Provincial Mexicano había dispuesto la conveniencia de que dentro de los hospitales hubiera “oratorio con cruz, imágenes y agua bendita...". Ver MARTÍNEZ, Luis (ed.). Decretos del Concilio Tercero Provincial Mexicano (1585). México: El Colegio de Michoacán-Universidad Pontificia de Santa Cruz, 2009. Volumen I, libro tercero, título 14 (De las casas religiosas y piadosas), p. 504. La disposición condujo a que se erigiesen capillas dentro de muchos de estos centros aunque en Michoacán muchos de ellos contaban ya con este espacio antes incluso de ser establecidas estas disposiciones conciliares.

${ }^{56}$ BASALENQUE, Fray Diego de. Historia de la provincia de San Nicolás. Libro I, cap. IIII, fol. 21 v.

${ }^{57}$ Resulta revelador que entre las disposiciones del Tercer Concilio Provincial Mexicano se inste a que “...en los hospitales donde ubiere capilla y concurre gente de fuera a oyr misa, no se dirá los domingos y fiestas de guardar, mientras en la iglesia parrochial se dixere la misa mayor...". MARTÍNEZ, Luis (ed.). Decretos del Concilio..., p. 50. Parece evidente que la "competencia" entre ambos espacios rituales era real y que las autoridades -con estas disposiciones- buscaban preservar el papel que le "correspondía" a la iglesia parroquial.

58 Obviamente, su riqueza ornamental dependió de las posibilidades materiales de cada hospital por lo que su aspecto externo e interno revelan de alguna manera la "salud" económica de estas instituciones y el estado de los bienes de comunidad del pueblo donde las capillas se ubicaban. A pesar de la simplicidad constructiva de la mayor parte de estos centros, algunas alcanzaron cotas notables. Son especialmente
} 
La importancia de estos lugares fue tal que, a lo largo de la época colonial, hubo pueblos en los que aún desaparecido el hospital, su capilla siguió celebrando culto ${ }^{60}$. Dicha importancia fue bien percibida por las autoridades civiles y religiosas. De hecho, cuando a principios del siglo XVII se pusieron en marcha nuevos procesos de congregación instando a los naturales al abandono de determinados asentamientos uno de los métodos coercitivos empleados fue, precisamente, la quema de estas capillas ${ }^{61}$.

El valor otorgado a estos edificios se vinculaba también con el hecho de que estos albergaban las imágenes sagradas ${ }^{62}$. Las cuentas de los hospitales revelan numerosos gastos relacionados con su compra así como partidas dedicadas al mantenimiento de las mismas. Sin duda, entre todas ellas destacan las imágenes de "bulto" de la Virgen de La Inmaculada Concepción ${ }^{63}$, patrona de la mayor parte de los

importantes las de los hospitales de la sierra, muchas de ellas construidas en el siglo XVII gracias a los ingresos de las curtidurías. Destacan, por ejemplo, las de Arantzan, Pomacuarán, Capácuaro y Charapan. Los hospitales de estos pueblos contaron con diferentes industrias y el comercio fue parte esencial de su desarrollo económico. Gracias a éste consiguieron importantes ingresos, parte de los cuales dedicaron al engrandecimiento de sus capillas. Existieron también capillas importantes en la zona lacustre, como las de Tzintzuntzan y Jarácuaro.

${ }^{59} \mathrm{La}$ importancia otorgada por los naturales a estos lugares fue bien percibida por las autoridades civiles y religiosas hispánicas. De hecho, cuando a principios del siglo XVII se pusieron en marcha nuevos procesos de congregación instando a los naturales al abandono de determinados asentamientos uno de los métodos coercitivos empleados fue, precisamente, la quema de estas capillas de los hospitales. A.G.N. (México), Congregaciones, Vol. I, Expediente 114, Hojas 68-68 v.

${ }^{60}$ El Obispado de Michoacán en el siglo XVII. Informe inédito de beneficios, pueblos y lenguas. Morelia: Fimax Publicistas, 1973. Esta obra, que fue realizada en 1631 por encargo del obispo fray Francisco de Ribera recoge cómo en esas fechas existían en la diócesis lugares a los que los naturales denominaban hospitales siendo tan sólo pequeñas capillas. Esto ocurría en los pueblos de Chiamila, Maquili, Acausitlán, Ixtlahuacan y Tamala, así como en el pueblo de Pomaro donde había unas ermitas a las que los indios llamaban generalmente hospitales aunque no lo eran pues, según el Informe, no poseían ni rentas ni propios ni se curaban en ellas enfermos; tan sólo servían para enseñar la doctrina a los naturales. Es evidente que, aún desaparecidas las funciones socio-económicas del hospital, pervivió su valor simbólico y, sobre todo, el uso comunitario del mismo vinculado de un modo particular a las funciones religiosas y a la ritualidad. Por extensión, esas pequeñas capillas siguieron denominándose hospitales y continuaron siendo un referente para el pueblo de indios que las albergaba lo que muestra la extraordinaria importancia de la institución hospitalaria dentro del imaginario indígena.

61 A.G.N. (México), Congregaciones, Vol. I, Expediente 114, Hojas 68-68 v.

62 Las imágenes, especialmente las marianas, jugaron un papel determinante en la penetración del cristianismo en el espacio americano. De hecho, el Primer Concilio Mexicano -anticipándose incluso a los decretos tridentinos- había favorecido su culto consciente del relevante papel que jugaba el elemento visual en un contexto marcado por la variedad y la multiplicidad lingüísticas. La imagen constituía un efectivo refuerzo de la palabra pero era también, en sí misma, un objeto valioso cargado de potentia. Por esa razón, además de actuar como un elemento de conversión y como un intermediario simbólico, las propias imágenes fueron también un bien muy preciado en su materialidad. Esto es especialmente evidente en el caso de las imágenes tridimensionales por su posibilidad de movilidad y por tanto de "expansión" y "esparcimiento" de su fuerza a través, por ejemplo, de traslados o procesiones.

${ }^{63}$ Grijalva, Basalenque y, posteriormente, Yssasy hacen mención expresa a las imágenes de bulto de La Concepción custodiadas en los hospitales. Véase GRIJALVA, Juan de. Crónica de la Orden de N.S.P. Agustín en las provincias de la Nueva España. México: Editorial Porrúa, 1985. BASALENQUE, Fray 
hospitales michoacanos ${ }^{64}$. Fruto de ese vínculo del hospital con la devoción mariana -y en particular con La Concepción-, las capillas hospitalarias recibieron comúnmente el nombre de yurixio, casa de la Virgen ${ }^{65}$.

Durante el primer siglo de vida de la diócesis la institución se extendió a lo largo y ancho del territorio transformándose en un auténtico geosímbolo ${ }^{66}$. Diversas fuentes nos muestran cómo, en Michoacán, los hospitales eran parte esencial del paisaje. Constituían los marcadores espaciales más característicos hasta el punto de configurar una geografía hospitalaria ${ }^{67}$. Así por ejemplo, el jesuita Sánchez Baquero insistía en su Crónica -escrita en el último cuarto del siglo XVI- en la presencia de esta institución en

Diego de. Historia de la Provincia de San Nicolás... Libro I, cap. II, fol. 11 v. YSASSI, Francisco Arnaldo de. Demarcación y descripción del obispado de Michoacán..., p. 142.

${ }^{64}$ SÁNCHEZ DEL OLMO, Sara. Tota pulchra... Culto y devoción a La Concepción en los hospitales de indios de Michoacán (1536-1640). Conferencia presentada en el XV Congreso Internacional de AHILA 1808-2008: Crisis y Problemas en el mundo atlántico. Simposio: Pensamiento religioso en el Antiguo Régimen Universidad de Leiden. Holanda (26-29 de agosto de 2008). http:www.leiden.edu/ahila2008

${ }^{65}$ En opinión de algunos autores esto convirtió al hospital en un ámbito exclusivamente femenino en una sociedad patriarcal. CASTRO GUTIÉRREZ, Felipe. Los tarascos..., p. 292. Si bien es cierto que la presencia femenina en la institución fue muy importante y que en ella $-\mathrm{y}$ de manera particular en sus capillas- las mujeres adquirieron un relevante papel en la ritualidad colectiva, no puede afirmarse que el hospital fuese un espacio exclusivamente femenino. Más bien al contrario, estos centros ponen en evidencia la continuidad del principio de la complementariedad y del binomio masculino-femenino característico de las culturas indígenas. Esto es visible, por ejemplo, a través de la participación en las tareas desarrolladas en el interior de la institución, compartidas por hombres y mujeres en igual número.

${ }^{66}$ Siguiendo a Bonnemaison definimos los geosímbolos como "un lugar, un itinerario, una extensión o un accidente geográfico que por razones políticas, religiosas o culturales revisten a los ojos de ciertos pueblos o grupos sociales una dimensión simbólica que alimenta y conforta su identidad". BONNEMAISON, Joël. Voyage autour du territoire. Espace géographique. Paris, tome 10, nº, pp. 249$262,1981$.

${ }^{67}$ Una de las primeras fuentes utilizadas para establecer una geografía de los hospitales en la diócesis de Michoacán es la Relación efectuada en 1569 por Juan Fernández Madaleno. El escribano señala que todos los pueblos contenidos en su relato, tanto cabeceras como sujetos, tenían sus hospitales, fundados la mayor parte por Vasco de Quiroga. Según este texto, en ese momento había en Michoacán 59 cabeceras y más de 300 sujetos. Las Relaciones Geográficas elaboradas en las dos décadas siguientes nos ayudan a dibujar una geografía hospitalaria. En ellas se menciona la presencia de hospitales para indios en 26 cabeceras y 32 sujetos aunque hay que tener en cuenta que las Relaciones abarcan una parte limitada del territorio michoacano. Por esa razón, éstas no mencionan centros que en esas fechas sí existieron. De hecho, el número de hospitales de indios existentes en la diócesis en el momento en que las Relaciones fueron redactadas fue superior al mencionado en las mismas. Si se asume la afirmación de Fernández Madaleno acerca de la existencia de hospitales de indios en cada una de las cabeceras y se completa con la información proporcionada por las Relaciones Geográficas, puede concluirse que en el último cuarto del siglo XVI hubo hospitales en 63 cabeceras de la diócesis michoacana. Más difícil resulta establecer el número de sujetos y barrios que contaron con ellos. A pesar de todo, en el último cuarto del siglo, está constatada la presencia de al menos 99 hospitales de indios en la diócesis michoacana. En 1631, un informe realizado por encargo del obispo fray Francisco de Ribera ponía en evidencia la extensión que la institución había alcanzado en el territorio michoacano. Dicho informe constata que en el primer tercio del siglo XVII había 257 hospitales de indios en esta diócesis. Aunque el Informe es muy completo, no es definitivo. Véase WARREN, Benedict; SÁNCHEZ DEL OLMO, Sara. Las guatáperas, hospitalitos y capillas de Michoacán. México: Ed. Carlos Trillas/Rotodiseño y Color, 2007. 
todos y cada uno de los pueblos de la diócesis, “...por muy pequeño que fuese" ${ }^{68}$. En similares términos se expresaba fray Alonso Ponce, quien en el relato de su viaje a las provincias franciscanas de la Nueva España (1584-1589), dejó por escrito la singularidad de este territorio remarcando la presencia de hospitales “...en todos los pueblos de la provincia" ${ }^{69}$. Cronistas posteriores como Grijalva hacen también referencia a la singularidad michoacana y aluden a la extensión de la institución por toda la diócesis ${ }^{70}$, al igual que los propios sucesores de Quiroga ${ }^{71}$. Fuera del ámbito religioso encontramos también referencias a esta particularidad del territorio michoacano. Así por ejemplo, Vázquez de Espinosa, en su obra Compendio y descripción de las Indias Occidentales, escrita en torno a 1625, aludía a la presencia de hospitales “...en todos los pueblos de indios de las provincias de este Obispado..."72. En los mismos términos se expresaba en fechas próximas el cronista holandés Joannes de Late, fundador de la Compañía Holandesa de las Indias Occidentales, quien al hablar de la diócesis de Michoacán refería: "Casi no hay una aldea que no tenga su hospital..."73 . Ya en el siglo XVIII, Juan José Moreno -el primer biógrafo de Quirogacontinuaba insistiendo en la presencia de esta institución en todos los pueblos de indios michoacanos $^{74}$.

De esta manera, a lo largo de la época colonial, el hospital de indios se convirtió en la entidad visual mas reconocible y reconocida del territorio. Era un lugar claramente

${ }^{68}$ SÁNCHEZ BAQUERO, Juan. Fundación de la Compañía de Jesús en la Nueva España. México: Editorial Patria, 1945. Cap. XIX, pp. 88-89.

${ }^{69}$ Relación breve y verdadera de algunas cosas de las muchas que sucedieron al Padre Fray Alonso Ponce en las provincias de la Nueva España. Madrid: Imprenta de la Viuda de Calero, 1873. Vol. I, pp. 524-525

${ }^{70}$ GRIJALVA, Juan de. Crónica de la Orden de N.S.P. Agustín... Libro Segundo, cap. IV, pp. 154-155.

${ }^{71}$ Así por ejemplo, en 1619, el obispo Baltasar de Covarrubias señalaba al rey Felipe II que todos los pueblos de indios del obispado poseían su hospital. Véase ALONSO, Carlos. Una carta del obispo Baltasar de Covarrubias, O.S.A., sobre la diócesis de Michoacán en 1619, Archivo Agustiniano. Valladolid, vol. LXXVI, nº 194, pp. 3-44, 1992.

72 VÁZQUEZ DE ESPINOSA, Antonio. Compendio y descripción de las Indias Occidentales. Washington: Smithsonian Miscellaneous Collections 108, 1948. Libro Tercero. cap. 27, p. 161.

73 LAET, Joannes de. Nuevo mundo o descripción de las Indias Occidentales. En: BOEHM DE LAMEIRAS, B.; SÁNCHEZ DÍAZ, G.; MORENO GARCÍA, H. Michoacán desde afuera, visto por algunos ilustres visitantes extranjeros. Siglos XVI al XX. Zamora (México): Gobierno del Estado de Michoacán - Instituto de Investigaciones Históricas, 1995, p. 109.

${ }^{74}$ MORENO, Juan José: Fragmentos de la vida y virtudes del V. Ilmo. Y Rvmo. Sr. Dr. Don Vasco de Quiroga, primer obispo de la santa iglesia catedral de Michoacán. Morelia: Balsal Editores, 1989. Libro I, cap. XII, pp. 69-70. Moreno señala en su obra que los hospitales eran “...el centro de la Religión, de la policía y de la humanidad de los Indios...". Al margen de las críticas que puedan hacerse a su interpretación, lo cierto es que en esas fechas, la institución continuaba siendo el lugar sobre el que pivotaba la vida social del pueblo de indios. 
identificable, con significado e identidad propios, un hito dentro de la nueva organización del espacio.

\section{La sacralización del espacio:}

Convertidos en elementos característicos e indispensables del paisaje michoacano, los hospitales constituyeron además el núcleo vertebrador de un proceso de sacralización del espacio.

La institución era un lugar estable y permanente en el que regularmente se manifestaba y vivía la sacralidad y se ponía en escena la religiosidad. Pero además, el hospital fue también un lugar de extroversión e irradiación del culto.

Como hemos señalado, una de las razones que contribuyeron a afianzar el carácter sacro de esta institución radica en el hecho de que esta albergaba imágenes devocionales, fundamentalmente marianas, sumamente preciadas para los naturales. Dichas imágenes tenían su residencia "fija" en el hospital pero de manera recurrente lo abandonaban, esparciendo así la fuerza de sus dones en el espacio. De esta manera, la sacralidad depositada en estos lugares emanó hacia el exterior a través de diferentes prácticas marcadas por la movilidad espacial ${ }^{75}$. Cada semana -coincidiendo con el cambio de semaneros- ${ }^{76}$, los naturales realizaban procesiones por el pueblo de indios. Cronistas como Grijalva ${ }^{77}$ y Basalenque $^{78}$ o autores como Ysassi ${ }^{79}$ refieren estas ceremonias y muestran cómo, periódicamente, la imagen abandonaba su "casa" y se hacía presente fuera de los muros del hospital creando circuitos litúrgicos internos dentro del pueblo de indios.

El hospital constituía así el punto de referencia de un ejercicio de sacralización del espacio cotidiano. Trasladar las imágenes residentes en estas instituciones hacia la

\footnotetext{
75 Como bien ha señalado Rosenhald, los espacios sagrados resultan de una combinación de diversos niveles: los "fijos" (el templo), los "no fijos-flujos" (los devotos, los peregrinos) y el imaginalis, el "círculo sagrado" que rodea el propio espacio, definido por la imaginación de los seguidores. ROSENHALD, Z. Hierópolis y procesiones: lo sagrado y el espacio. En : CARBALLO, C. (coord.). Cultura, territorios y prácticas religiosas. Buenos Aires: Prometeo, 2009, pp. 43-56.

${ }^{76}$ Los indios, hombres y mujeres, acudían por turnos semanales a prestar servicio en la institución por lo que recibieron el nombre de "semaneros".

${ }^{77}$ GRIJALVA, Juan de. Crónica de la Orden de N.S.P. Agustín en las provincias de la Nueva España. México: Editorial Porrúa, 1985.
}

78 BASALENQUE, Fray Diego de. Historia de la provincia de San Nicolás de Tolentino de Michoacán [1673]. Morelia (México): Balsal Editores, 1989.

${ }^{79}$ YSASSI, Francisco Arnaldo de. Demarcación y descripción del obispado de Michoacán..., p. 142. 
iglesia -o incluso hacia el ámbito privado como las casas de los naturales- suponía en realidad trasladar lo sagrado mas allá de los muros del hospital sacralizando con su desplazamiento los lugares por los que transitaban y, por supuesto, las residencias temporales que las albergaban. El espacio social quedaba así impregnado del carácter sacro de la imagen.

Por otro lado, los traslados de las imágenes residentes en la capilla del hospital no se circunscribían a los límites del pueblo (cabecera, barrio o sujeto) que las albergaba. Juan González de la Puente refiere en su Crónica una de estas visitas exteriores asociada a la recogida de limosnas para el hospital. El cronista narra la preparación de los naturales ante la llegada de la imagen y refiere cómo -a su arribo al pueblo de acogida- ésta fue ubicada, precisamente, en la capilla del hospital. Allí permaneció durante tres días en los que fue velada día y noche por cada uno de los barrios que componían el pueblo de indios y, posteriormente, recorrió las casas de los naturales. De esta manera, la fuerza sagrada de la imagen se hizo presente en el espacio socio-religioso más importante del pueblo receptor, el hospital, y en los propios espacios privados de los naturales ${ }^{80}$.

En ocasiones, incluso, algunas de esas imágenes de bulto de la Virgen se trasladaron a lugares muy alejados de su "casa original" generando, a partir del espacio hospitalario, una fuerte corriente devocional. Habitualmente, no fueron las imágenes "originales" las que efectuaron estos viajes sino pequeñas réplicas -en ocasiones realizadas a partir de fragmentos de la imagen original- denominadas "Peregrinas". Gracias a estos desplazamientos esas imágenes serían veneradas no sólo en el interior de los hospitales o en el pueblo de indios que las albergaban sino también en esos territorios visitados en sus viajes ${ }^{81}$. De esta manera, el hospital se convirtió en el eje de un proceso de sacralización del espacio que rebasó los límites físicos de la institución.

\section{Los hospitales de indios, lugares de identidad:}

Pese a tratarse de una institución foránea e "impuesta", desde fechas tempranas los naturales vieron en los hospitales un lugar de referencia. La capacidad de la institución para articular la vida social del pueblo de indios y, muy especialmente, las

\footnotetext{
${ }^{80}$ PUENTE, Juan González de la. Crónica de la Orden de San Agustín en Michoacán. En: PLANCARTE Y NAVARRETE, F. (ed.). Colección de documentos inéditos y raros para la historia eclesiástica mexicana. México: R.C. Miranda, 1907. Cap. XXXXIX, pp. 325-326.

81 SÁNCHEZ DEL OLMO, Sara. Imagen mariana y construcción de la identidad socio-religiosa en el Michoacán colonial. Dimensión antropológica. México, año 19, vol. 55, mayo-agosto, pp. 71-91, 2012.
} 
posibilidades que esta ofrecía para mantener vigentes determinados principios de la organización social prehispánica -como la importancia de los linajes- provocaron una fuerte identificación de los indígenas con el lugar y, a través de un proceso de apropiación, éste quedó convertido en un espacio simbólico indispensable en la reconstrucción de la identidad.

La propia ubicación del hospital dentro del pueblo de indios contribuyó a reforzar el vínculo -espacial y simbólico- con el lugar. Así por ejemplo, en San Antonio Charápani, tras el proceso de congregación, los cuatro barrios fundadores del pueblo de indios se orientaron hacia cada uno de los cuatro puntos cardinales ${ }^{82} \mathrm{y}$, al tiempo, respetaron la tradicional subdivisión que los agrupaba (y separaba) en barrios o parcialidades del "arriba” y del "abajo". Al mismo tiempo, siguiendo los nuevos presupuestos ideológicos, los barrios se dispusieron figurando simbólicamente una gran cruz acostada cuya cabeza se dirigía hacia el este, el lugar por donde sale el sol. Cada uno de ellos estaba a su vez marcado por la presencia sacralizadora y material de una cruz. Lo interesante es que, desde el punto de vista espacial, todos los barrios se ubicaron alrededor de la capilla del hospital, dedicada a La Concepción ${ }^{83}$. De esta manera, en Charápani -como en la mayor parte de los pueblos de indios michoacanos- el hospital constituía el corazón físico y simbólico de la población, el núcleo vertebrador de las parcialidades ${ }^{84}$.

Por otro lado, los hospitales jugaron un papel fundamental en la reelaboración de los mapas mentales de los naturales. El reordenamiento del territorio nacido tras la conquista obligó a los indígenas a establecer nuevas relaciones entre el espacio construido, el espacio natural y los espacios de pertenencia, a dotar de significado a

\footnotetext{
${ }^{82}$ En época prehispánica, los tarascos creían que vivían sobre la espalda de una diosa madre que estaba acostada sobre su vientre mientras otras deidades la tomaban por la cabeza, los pies y los brazos extendidos. De esta manera se conformaban los cuatro puntos cardinales y sus deidades correspondientes. ${ }^{83}$ La capilla miraba hacia el poniente y su orientación hacía que, al caer el Sol, la luz penetrase en el interior de este recinto sagrado iluminando intensamente -en determinadas épocas del año - el altar donde se ubicaba la imagen mariana propiedad del hospital. GARCÍA MORA, Carlos. El espacio y el tiempo purépechas..., pp. 12-15. A lo largo de la época colonial, la cruz atrial de la capilla del hospital dejó de señalar el centro del pueblo de indios al ser relegada por la cruz del templo parroquial levantado, al parecer, en época posterior. Convertido en espacio religioso central, el templo desplazo -física y simbólicamente- al hospital. En opinión de García Mora pudo ser un intento de las jerarquías religiosas por restar relevancia a este último.

${ }^{84} \mathrm{El}$ análisis de la organización interna del trabajo en los hospitales de indios revela que éste tenía carácter rotatorio y estaba establecido mediante un sistema de turnos. Se trataba organizado espacial y familiarmente de manera que cada uno de los barrios vinculados al hospital rotaba en las obligaciones contraídas con éste. De este modo, el hospital fue un lugar privilegiado para el mantenimiento de formas culturales estrechamente vinculadas al sistema de parentesco.
} 
lugares desconocidos y a resemantizar los propios. El proceso trajo consigo además la imposición de nuevos marcadores visuales pero posibilitó también la introducción de nuevos referentes espaciales hasta entonces desconocidos. Es indudable que esa incorporación hubo de provocar, especialmente en los primeros momentos, ciertas tensiones en la percepción del paisaje, un forcejeo entre los viejos y los nuevos hitos.

Pese a todo, se produjo una reformulación de los vínculos con el territorio, reformulación en la que el hospital estuvo bien presente. Así por ejemplo, en Guanajuato, el análisis de la ubicación del hospital de $\operatorname{tarascos}^{85}$, muestra que el eje longitudinal de la capilla pasa -en primer lugar- por la cruz atrial, continua después hacia la cima del cerro de San Miguel, y prosigue hasta rematar en la cascada La Tzaráracua (a más de 200 kilómetros al sur-suroeste de Guanajuato) no sin antes haber cruzado Uruapan, la cabecera de una de las regiones de donde procedían los tarascos instalados en la ciudad. En el caso del hospital de otomíes, el eje longitudinal de su capilla remata en la gigantesca Peña de Bernal, ubicada precisamente en tierras otomíes de Querétaro, a más de 100 kilómetros al oriente de Guanajuato. Ambos alineamientos se relacionan con accidentes geográficos significativos que no están escogidos al azar. Es posible así advertir la voluntad de establecer nuevos vínculos territoriales manteniendo al mismo tiempo las referencias a los espacios originarios de pertenencia ${ }^{86}$.

\footnotetext{
${ }^{85}$ El obispado de Michoacán no fue un espacio homogéneo desde el punto de vista étnico: en la época prehispánica el área estuvo ocupada no sólo por tarascos sino por mexicas, otomíes, chichimecas sometidos y otros grupos étnicos de menor cuantía. Las relaciones de los tarascos -el grupo predominante- con estas etnias fueron cambiantes y no siempre pacíficas. La presencia de grupos foráneos se incrementaría tras la conquista debido a diferentes factores: por un lado, las alianzas establecidas por los conquistadores con determinadas etnias y la ayuda prestada por estas en el avance hispánico hacia la frontera chichimeca (como en el caso de los otomíes); por otro, los trasvases y movimientos de población asociados al trabajo en las minas; y, finalmente, los efectos de las congregaciones que desplazaron -en ocasiones a muy larga distancia- a numerosos grupos. A partir de esos elementos se configuró un espacio multiétnico y multilingüe en el que aparecieron pueblos de indios donde coexistieron etnias distintas. Los naturales no siempre aceptaron de buen grado esa convivencia, habitualmente impuesta. Cuando a pesar de sus diferencias étnicas los naturales fueron obligados a compartir un mismo espacio las "estrategias" identitarias seguirían caminos diversos. El hospital se convirtió en un espacio privilegiado para visualizar, mantener y reforzar las diferencias. De este modo, en algunos de los lugares donde se produjo la coexistencia de etnias distintas se erigieron hospitales diferenciados para cada una de ellas. En Santa Fe de Guanajuato llegarían a contarse tres hospitales de indios vinculados a la calidad étnica: uno de tarascos, otro de otomíes y otro de mexicanos. De esta manera, el hospital funciono también -en algunos pueblos de indios michoacanos- como marca identitaria y distintiva en un espacio marcado por la heterogeneidad étnica.

86 PARRA MORENO, Arturo. La sacralización urbana y regional de Guanajuato, México, 1554-1663. En : Territorio, Arte, Espacio y Sociedad. Actas del III Congreso Internacional del Barroco Americano. Sevilla: Universidad Pablo de Olavide, 2001, pp. 1112-1120. En opinion de Parra, los rumbos y la orientación de los hospitales, además de corresponder a las tierras de origen de los indigenas, estarian
} 
De esta manera, simbiosis culturales confluyeron para contribuir a dar forma a una trama espacial generadora de un nuevo orden simbólico en el que el hospital constituyó un elemento central.

Finalmente, el hospital parece haber sido un lugar privilegiado para la preservación de una memoria espacial vinculada a la identidad. Así por ejemplo, en Tzintzuntzan, diversas piezas arquitectónicas de origen prehispánico -en concreto las losas denominadas janamus- fueron reutilizadas en la época colonial y aparecen empotradas en la capilla del hospital. En opinión de Hernández Díaz (2006), es muy posible que los naturales -y en particular las élites indígenas- emplearan de modo intencional estas piedras con imágenes antiguas que les eran propias y significativas, y tal vez incluso sagradas. No hay que olvidar que los janamus habían formado parte de la principal arquitectura ceremonial de Tzintzuntzan, el centro de la autoridad política michoacana durante la época prehispanica ${ }^{87}$. Por otra parte, autores como Duverger (2003) han señalado que, en ocasiones, los naturales establecieron un paralelismo entre los nuevos espacios sagrados (iglesias y capillas) y las grutas. Dentro de la cosmovisión indígena, estas últimas estaban asociadas al corazón de la montaña, a las entrañas de la tierra y a las fuerzas fecundadoras; eran, en suma, el acceso al origen. Según este autor, los naturales representaron el glifo de la montaña en algunas de las nuevas construcciones religiosas especialmente significativas para ellos. Es el caso, por ejemplo, del hospital de Uruapan $^{88}$. Aunque se trata de dos ejemplos aislados que no permiten establecer generalizaciones, resulta sumamente significativo que los naturales escogieran los hospitales -y mas precisamente las capillas, su espacio mas sagrado- para ubicar los janamus y los glifos prehispánicos.

A lo largo de la época colonial la institución constituyó un lugar central. Nuevo hito, marcador emblemático y centro físico y simbólico de la nueva organización espacial, el hospital de indios michoacano devino un elemento fundamental en la reconstrucción de la identidad y en la reelaboración de los nuevos mapas mentales del territorio. Su huella quedó fijada en el imaginario indígena hasta tal punto que, hasta el

vinculados a eventos cristianos "primigenios". Los religiosos habrian escogido los emplazamientos para reforzar el caracter sagrado de esos nuevos espacios nacidos a una nueva fe.

87 HERNÁNDEZ DÍAZ, Verónica. Los janamus grabados de Tzintzuntzan. Anales del Instituto de Investigaciones Estéticas. México, nº 89, pp. 197-212, 2006.

88 DUVERGER, Christian. Agua y fuego. Arte sacro indígena de México en el siglo XVI. México: Santander-Serfin, 2003, p. 112. 
día de hoy, en numerosos pueblos michoacanos el hospital (sus restos arquitectónicos o el espacio físico que un día ocupó) poseen un fuerte poder evocador y constituyen aún el lugar de reunión de la comunidad. Así por ejemplo, en Aranza, en el sitio que un día ocupó el hospital se asientan hoy la jefatura de tenencia (donde se tratan los asuntos políticos) y la Casa del Pueblo (cuyos inmuebles cumplen funciones sociales). En otros casos, aún desaparecida la institución, permanecen vigentes los usos y costumbres tradicionalmente asociados a ella. Así, en Ahuiran, la destrucción física y los cambios de uso del edificio que en su día fue el hospital no han impedido que, cada 8 de diciembre -festividad de La Concepción- se sigan escogiendo allí los cargos rectores ${ }^{89}$. El lugar permanece vivo en la memoria colectiva ${ }^{90}$ y constituye un espacio simbólico estrechamente vinculado a la cohesión social y a la identidad.

\section{Conclusiones:}

La conquista de la Nueva España trajo consigo un proceso de reorganización del territorio que implicó el diseño de nuevos modelos urbanos. Estos constituyen el eje y el reflejo de un sistema de producción y organización del poder. Por esa razón, su forma física y su implementación pueden ser analizadas como la expresión de un proyecto ideológico. Cada discurso urbano desplegado en América -y en particular en la Nueva España- jugó un papel estratégico en el proceso de colonización, aculturación y cambio cultural. Más allá de su capacidad y efectividad real, todos ellos buscaron contribuir a la construcción de un nuevo sujeto social. El espacio como los propios habitantes- debía ser "domesticado".

En ese intento de "domesticación", las autoridades hispánicas fomentaron la implantación de instituciones peninsulares destinadas -en principio- a incorporar a los indígenas a la vida "civilizada". Entre esas instituciones se hallaban, precisamente, los hospitales. Pese a todo, la propuesta tuvo un desarrollo muy limitado en Nueva España a excepción de un territorio: Michoacán. Aquí, el hospital encontró un férreo defensor en la figura del primer obispo de la diócesis. No obstante, su extraordinario éxito ha de vincularse al interés despertado en los naturales por la institución.

\footnotetext{
${ }^{89}$ GUTIÉRREZ EQUIHUA, Angel. Los hospitales de la sierra tarasca en el el siglo XVII. Tesis de maestria (publicacion electronica). Universidad Michoacana de San Nicolás de Hidalgo. Morelia, 2007, pp. 83 y 167.

${ }^{90}$ No obstante, es preciso recordar que la memoria puede ser -como bien ha senalado Jelin- un agente de cambio del mundo social, puede ayudar a institucionalizar la identidad de un grupo o, incluso, contribuir a fundamentar la exclusión. Sobre el papel actual de los hospitales en la construccion de la memoria entre los indigenas michoacanos y el uso del patrimonio historico para la construccion de identidades culturales excluyentes véase el trabajo de Jiménez RAMÍREZ, Mauricio Benjamín. La construcción del discurso del patrimonio en la Huatápera de Uruapan. Participación, ciudad y etnia en la emergencia de nuevas formas políticas. Tesis de maestria (publicacion electronica). Instituto Tecnológico y de Estudios Superiores de Occidente. Jalisco, 2010.
} 
Desde fechas tempranas, el hospital se reveló como un lugar privilegiado para la vivencia de lo sagrado, carácter que quedó reforzado por la presencia de pequeñas capillas anexas que contenían las imágenes marianas. Durante el primer siglo de vida de la diócesis los hospitales de indios se extendieron a lo largo y ancho del territorio transformándose en un auténtico geosímbolo y configurando una verdadera geografía hospitalaria.

La sacralidad depositada en estos lugares emanó hacia el exterior a través de diferentes prácticas vinculadas a las imágenes marianas y marcadas por la movilidad espacial. Estos desplazamientos -locales, supra-locales e, incluso, regionalespermitieron establecer estrechas y permanentes relaciones sociales que rebasaron con creces los límites del pueblo de indios. Pero sobre todo, contribuyeron a marcar, delimitar y sacralizar el espacio michoacano al definir caminos sagrados por los que transitó la devoción.

A pesar de su carácter foráneo, los naturales se apropiaron pronto de la institución e iniciaron un proceso de identificación simbólica con ésta. El hospital, dadas sus características, permitió dar sentido, estabilidad y continuidad al pueblo de indios como cuerpo social, de ahí que se convirtiera en un lugar de referencia y de pertenencia, en un elemento esencial en la reformulación de la identidad.

Finalmente, los hospitales jugaron un papel central en la reelaboración de los referentes espaciales. La reorganización del territorio llevada a cabo tras la conquista provocó la ruptura de los nexos topográficos, especialmente en el campo de lo sagrado. Esa fractura obligó a los naturales a reformular sus mapas mentales, a establecer nuevos marcadores. En Michoacán, el hospital devino un elemento sustancial en la reconstrucción de los vínculos de los naturales con el espacio. Lugar central dentro de la trama espacial, a partir de él fue posible construir un nuevo orden simbólico. Pero sobre todo, a través de él fue posible garantizar la vivencia y la pervivencia espacial de lo sagrado. 


\section{Referencias}

ALONSO, Carlos. Una carta del obispo Baltasar de Covarrubias, O.S.A., sobre la diócesis de Michoacán en 1619. Archivo Agustiniano. Valladolid, vol. LXXVI, no 194, pp. 3-44, 1992.

BASALENQUE, Fray Diego de. Historia de la provincia de San Nicolás de Tolentino de Michoacán [1673]. Morelia (México): Balsal Editores, 1989.

BELTRÁN, Ulises. Estado y sociedad tarascos en la época prehispánica. En: BOEHM DE LAMEIRAS, Brigitte (coord.). El Michoacán Antiguo, Estado y Sociedad Tarascos en la Época Prehispánica México: COLMICH y Gobierno del Estado de Michoacán, 1994.

BONNEMAISON, Joël. Voyage autour du territoire. Espace géographique. Paris, tome 10, $\mathrm{n}^{\circ} 4$, pp. 249-262, 1981.

CARrillo CÁZARES, Alberto. Michoacán en el otoño del siglo. Zamora (México): El Colegio de Michoacán, 1993.

CASTRO GUTIÉRREZ, Felipe. Los tarascos. México: UNAM, 2004.

CÉSAR VILLA, Ma Guadalupe. Las congregaciones de tres pueblos de indios en tres partidos serranos y sus consecuencias en el siglo XVII. En: En: PAREDES, Carlos (dir.). Arquitectura y espacio social en poblaciones purépechas de la época colonial. Morelia: Universidad Michoacana de San Nicolás de Hidalgo, 1998.

CLAVAL, P. La geografía cultural. Buenos Aires: Editorial Universitaria (EUDEBA), 1999.

DURSTON, Alan. Un régimen urbanistico en la América hispana : el trazado en damero durante los siglos XVI y XVII. Historia. Santiago (Chile), vol. 21, pp. 59-115, 1994.

DUVERGER, Christian. Agua y fuego. Arte sacro indígena de México en el siglo XVI. México: Santander-Serfin, 2003

El Obispado de Michoacán en el siglo XVII. Informe inédito de beneficios, pueblos y lenguas. Morelia: Fimax Publicistas, 1973.

GARCÍA CASTRO, René. Indios, territorio y poder en la provincia Matlatzinca. La negociación del espacio político de los pueblos otomianos, siglos XV-XVII. México: CIESAS-I.N.A.H.-El Colegio Mexiquense, 1999.

GARCÍA MORA, Carlos. El espacio y el tiempo purépechas. Intersección cardinal en un poblado de la Sierra de Michoacán (ed. Electrónica). México: Tsimarhu Estudio de Etnólogos, 2014.

GERHARD, Peter. Congregaciones de indios en la Nueva España antes de 1570. En: Los pueblos de indios y las comunidades (Bernardo García, introducción y selección). México: El Colegio de México, 1991.

Geografía histórica de la Nueva España, 1519-1821. México: UNAM, 1986.

GRIJALVA, Juan de. Crónica de la Orden de N.S.P. Agustín en las provincias de la Nueva España. México: Editorial Porrúa, 1985.

GUTIÉRREZ EQUIHUA, Angel. Los hospitales de la sierra tarasca en el el siglo XVII. Tesis de maestria (publicacion electronica). Universidad Michoacana de San Nicolás de Hidalgo. Morelia, 2007.

HERNÁNDEZ DÍAZ, Verónica. Los janamus grabados de Tzintzuntzan. Anales del Instituto de Investigaciones Estéticas. México, nº 89, pp. 197-212, 2006. 
LAET, Joannes de. Nuevo mundo o descripción de las Indias Occidentales. En: BOEHM DE LAMEIRAS, B.; SÁNCHEZ DÍAZ, G.; MORENO GARCÍA, H. Michoacán desde afuera, visto por algunos ilustres visitantes extranjeros. Siglos XVI al XX. Zamora (México): Gobierno del Estado de Michoacán - Instituto de Investigaciones Históricas, 1995.

LÓPEZ SARRELANGUE, Delfina Esmeralda. La nobleza indígena de Pátzcuaro en la época virreinal. México: UNAM-Instituto de Investigaciones Históricas, 1965.

MARTíneZ, Luis (ed.). Decretos del Concilio Tercero Provincial Mexicano (1585). México: El Colegio de Michoacán-Universidad Pontificia de Santa Cruz, 2009.

MONZÓN, Cristina. Los principales Dioses Tarascos: un ensayo de análisis etimológico en la Cosmología Tarasca. Relaciones. Zamora (Michoacán), vol. XXVI , 104, pp. 136-168, 2005.

MORENO, Juan José: Fragmentos de la vida y virtudes del V. Ilmo. Y Rvmo. Sr. Dr. Don Vasco de Quiroga, primer obispo de la santa iglesia catedral de Michoacán. Morelia: Balsal Editores, 1989.

MOYA PONS, Frank. Después de Colón. Trabajo, sociedad y política en la economía del oro. Madrid: Alianza Editorial,1987.

PAREDES MARTÍNEZ, Carlos. Gobierno y pueblos de indios en Michoacán en el siglo XVI. En: PAREDES, Carlos (dir.). Arquitectura y espacio social en poblaciones purépechas de la época colonial. Morelia: Universidad Michoacana de San Nicolás de Hidalgo, 1998.

PARRA MORENO, Arturo. La sacralización urbana y regional de Guanajuato, México, 1554-1663. En : Territorio, Arte, Espacio y Sociedad. Actas del III Congreso Internacional del Barroco Americano. Sevilla: Universidad Pablo de Olavide, 2001.

PUENTE, Juan González de la. Crónica de la Orden de San Agustín en Michoacán. En: PLANCARTE Y NAVARRETE, F. (ed.). Colección de documentos inéditos y raros para la historia eclesiástica mexicana. México: R.C. Miranda, 1907.

RAMÍREZ, Mauricio Benjamín. La construcción del discurso del patrimonio en la Huatápera de Uruapan. Participación, ciudad y etnia en la emergencia de nuevas formas políticas. Tesis de maestria (publicacion electronica). Instituto Tecnológico y de Estudios Superiores de Occidente. Jalisco, 2010 .

RAMÍREZ, Francisco. El Antiguo Colegio de Pátzcuaro (Germán Viveros, ed.), Zamora (Michoacán), COLMICH, 1987.

REA, Alonso de la. Crónica de la Orden de N.S.P. San Francisco, Provincia de San Pedro y San Pablo de Michoacán en la Nueva España [1643]. Edición y estudio introductorio de Patricia ESCANDÓN. Zamora (México): El Colegio de Michoacán, 1996.

Relación de Michoacán. Versión paleográfica e introducción de Armando Mauricio Escobar Olmedo. Madrid: Testimonio Compañía Editorial, 2001.

Relación breve y verdadera de algunas cosas de las muchas que sucedieron al Padre Fray Alonso Ponce en las provincias de la Nueva España. Madrid: Imprenta de la Viuda de Calero, 1873.

REVILLA, Federico. Diccionario de iconografía y simbología. Madrid: Editorial Cátedra, 1999.

ROSENHALD, Z. Hierópolis y procesiones: lo sagrado y el espacio. En : CARBALLO, C. (coord.). Cultura, territorios y prácticas religiosas. Buenos Aires: Prometeo, 2009.

SÁNCHEZ BAQUERO, Juan. Fundación de la Compañía de Jesús en la Nueva España. México: Editorial Patria, 1945.

SÁNCHEZ DEL OLMO, Sara. Imagen mariana y construcción de la identidad socio-religiosa en el Michoacán colonial. Dimensión antropológica. México, año 19, vol. 55, mayo-agosto, pp. 71-91, 2012.

El texto como pretexto. Un relato histórico sobre la fundación de un pueblo de indios en el Michoacán colonial. En : SÁNCHEZ BAENA, J.J., PROVENCIO GARRIGÓS, L., coord.). EI Mediterráneo y América, vol. 2. Murcia: Universidad de Murcia, 2006, pp. 765-779.

Les hôpitaux d'indiens au Michoacan : survivance et appropriation culturelle à 
la Nouvelle Espagne (1536-1639). En: GRUNBERG B. (ed.). Le contrôle de la vie religieuse en Amérique. Paris : L’Harmattan, 2008.

Tota pulchra... Culto y devoción a La Concepción en los hospitales de indios de Michoacán (1536-1640). Conferencia presentada en el XV Congreso Internacional de AHILA 1808-2008: Crisis y Problemas en el mundo atlántico. Simposio: Pensamiento religioso en el Antiguo Régimen Universidad de Leiden. Holanda (26-29 de agosto de 2008). http:www.leiden.edu/ahila2008

SEBASTIÁN LÓPEZ, Santiago. Espacio y símbolo, Córdoba, Universidad de Córdoba, 1977.

SOLANO, Francisco de. Ciudades hispanoamericanas y pueblos de indios. Madrid: CSIC, 1990.

Normas y leyes de la ciudad hispanoamericana. 1492-1600, Madrid: CSIC, 1996.

Urbanización y municipalización de la población indígena. En: SOLANO, Francisco de (coord..). Estudios sobre la ciudad iberoamericana. Madrid: CSIC, 1983.

TAYLOR, William. Ministros de lo sagrado. Zamora (México): El Colegio de Michoacán, 1999.

TORRE VILLAR, Ernesto de la. Las congregaciones de los pueblos de indios. Fase terminal: aprobaciones y rectificaciones. México: UNAM, 1995.

VÁZQUEZ DE ESPINOSA, Antonio. Compendio y descripción de las Indias Occidentales. Washington: Smithsonian Miscellaneous Collections 108, 1948.

VIÑUALES, Graciela M.; GUTIÉRREZ, Ramón y otros. Iberoamérica siglos XVI-XVIII. Tradiciones, utopías y novedad cristiana. Madrid: Ediciones Encuentro, 1992.

WARREN, Benedict; SÁNCHEZ DEL OLMO, Sara. Las guatáperas, hospitalitos y capillas de Michoacán. México: Ed. Carlos Trillas/Rotodiseño y Color, 2007.

YSASSI, Francisco Arnaldo de. Demarcación y descripción del obispado de Michoacán y fundación de su catedral. Biblioteca Americana, University of Miami, Station Coral Gables, Florida, vol.1, $\mathrm{n}^{\circ}$, pp. 61-209, 1982.

ZAVALA, Silvio. El servicio personal de los indios en la Nueva España-I (1521-1550). México: El Colegio de México, 1984.

Recebido: $18 / 11 / 2015$

Received: $11 / 18 / 2015$

Aprovado: $03 / 12 / 2015$

Approved: 12/03/2015 